\title{
Comparative Study of Water Resource Management and Policies for Ecosystems in China and Denmark
}

\author{
L. Y. Su ${ }^{1,2, *}$, P. Christensen ${ }^{2}$, and J. L. Liu ${ }^{1}$ \\ ${ }^{1}$ State Key Joint Laboratory of Water Environmental Simulation and Pollution Control \& School of Environment, \\ Beijing Normal University, Beijing 100875, China \\ ${ }^{2}$ Department of Development and Planning, Aalborg University, Fibigerstraede 13, 9220, Aalborg, Denmark
}

Received 9 January 2012; revised 28 December 2012; accepted 8 March 2013; published online 31 March 2013

\begin{abstract}
This paper compares water resource policies and management practices in China and Denmark. It takes two vulnerable water ecosystems as case studies: Baiyangdian wetland in China and Mariager fjord in Denmark. Based on the theories of the commons, this article explores the similarities and differences between the two ecosystems in terms of ecosystem characteristics, historical and cultural backgrounds of these societies, the technologies affecting the ecosystems and also how the ecosystems have been seen at different times as well as the existence of property rights through time. Both water bodies have experienced drastic and devastating impacts from human activities. The analysis shows both in Denmark and China, it can be expected that goals, once they are decided, will be implemented. But, in reality, it seems that this will be much easier to accomplish in Denmark than in China, probably due to the complicated administrative structure in China and clearer goals and better resources in Denmark. Denmark has also accomplished a large degree of environmental policy integration (EPI), which is not the case in China. But China has recently put environmental concerns high on the agenda, giving priority to environmental concerns, even highlighting sustainability as a future developmental goal. Denmark has also established a much more effective regulation of the different sectors contributing to the pollution of the ecosystems than China has.
\end{abstract}

Keywords: China, comparative analysis, Denmark, environmental legislation, resource management, water management

\section{Introduction}

For many years, humans have caused impacts on and transformed wetlands, lakes and rivers in order to make them fit their own needs, be it for agriculture, waste-water discharge, navigation or fishing. In recent centuries, these changes have been particularly dramatic, especially those caused by increases in populations and the rise of industrial production. In recent decades, this has led to increased interest in restoring these often vulnerable ecosystems, particularly after the United Nations Stockholm conference in 1972, where many countries, including Denmark and China, launched such policies.

Nature protection has been an issue in Denmark for many years. The first Law on Nature Conservancy was passed in 1916 and in the 1970s a range of laws were passed that was designed to protect the environment. In the 1980s, the focus was on agricultural production with a range of action plans drawn up to protect the aquatic environment. Since then, EU directives on the protection of birds (1979) and of habitats

\footnotetext{
* Corresponding author. Tel.: +86 1058805092 ; fax: +86 1058800397. E-mail address: liyasu0603@163.com (L. Y. Su).
}

ISSN: 1726-2135 print/1684-8799 online

(C) 2013 ISEIS All rights reserved. doi:10.3808/jei.201300234
(1992) have formed a new basis for protecting and restoring the environment. The overall policies are now that the decline in biodiversity should be stopped by 2010 - now postponed to 2020 - and that good ecological conditions should be found in all natural water bodies by 2015 .

China also has a long history of protecting the environment. A Fishery Law was passed as early as 1929 and part of its goal was to protect the environment of the fish. The Environmental Protection Law of the People's Republic of China was first launched in 1979 and later amended in 1989, and it is now the basis for environmental protection activities. Over the last 10 years in particular a series of laws have been established covering, for example, the prevention of water pollution. The Chinese government and the public now pay great attention to environmental protection while still experiencing continuing and rapid economic development, so the challenge now is to resolve the contradictions between economic development and environmental protection.

In this article, we compare the environmental policies and practices in Denmark and China. Our main interest is to describe the different water policies in the two countries and how they have developed since the 1970s, using a case study from each country with special emphasis on how the two different sets of political framework contribute to the protection and restoration of the environment. 


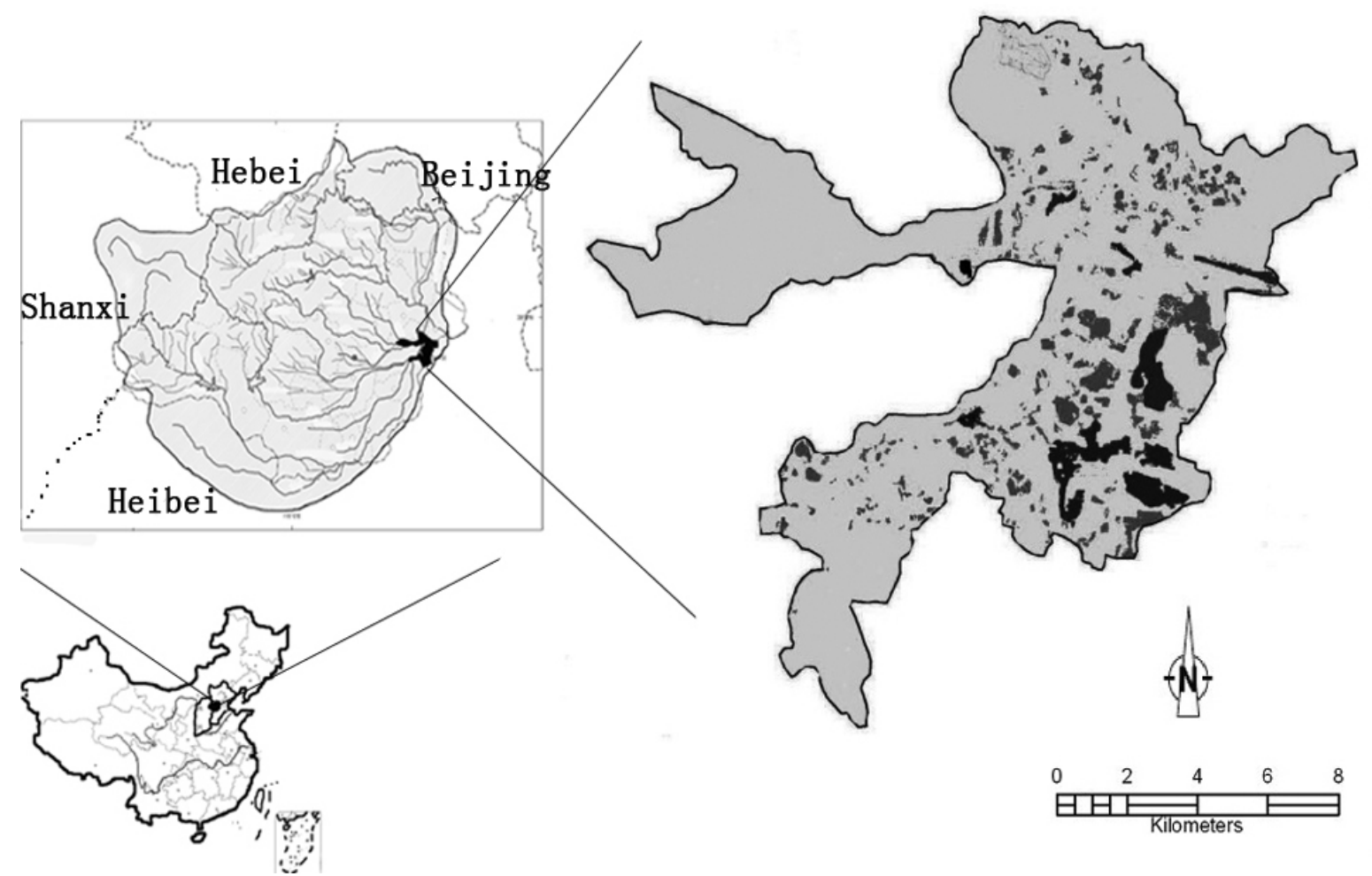

Figure 1. The location of Baiyangdian wetland.

\section{Theoretical Background for the Comparisons}

Back in 1968, the American ecologist Garret Hardin addressed the problem of wise resource use through the simple parable of the 'tragedy of the commons' (Hardin, 1968). The pivotal question in determining the fate of a resource is, according to Hardin, that of the ownership (Hardin, 1968). Common resources have a tendency to become overexploited and the normal solution to this problem is to privatize this property. But resource use cannot be seen as property owners versus free riders overexploiting the resource. Recent research on how resources are used showed that this is determined by many factors other than just ownership (Ostrom, 1999). Resource use is governed by a complicated relationship among the kinds of resources in question, the kind of property regime related to this (be it private, state or community), and the duties and routines as well as conceptions generally institutionalized between the parties using the resource (Hanna and Munasinghe, 1995; Ostrom et al., 1999). It also involves a complicated relationship between the physical characteristics of the resource in question and the technologies affecting it (Commoner, 1971), as well as the forms of duties and obligations for its use as they become developed in the fabric of society (Costanza and Folke, 1996).

The characteristics of commons vary a lot and the climate system, the fish resources of the sea and biodiversity cannot be treated alike. Our cognitive understanding of common re- sources often changes over time as scientific knowledge and relevant basic ideas develop. These ideational pictures or ideas of the resource continuously change, and sometimes radically if paradigmatic shifts occur (Kuhn, 1962; Commoner, 1971).

It is a characteristic of commons that they were once free in the sense that (some) people from local communities had free access to them, but one party's use of it normally diminished the possibility of other people using it (Ostrom et al., 1999). The use of resources, in positive cases, is governed by a set of institutionalized rights and duties. This includes property rights, the right to use the resources, schemes for when and where the resource can be used, and also rules for monitoring and controlling its use. Besides privatizing property and state regulation, a wide range of community-based rules and institutions cover the regulatory aspects of institutions, and normative and cognitive aspects affect the setting of rules in society (DiMaggio and Powell, 1983; Scott, 2001). During the last 40 years, growing pressure on states, bureaucracies and industries has emanated from the UN and other international organizations (March and Olsen, 1989; Meyer, 1994), so that there is now constant institutional pressure for environmental change. Quite often the response is uniform, creating isomorphy (Scott, 2001). Over recent years, it has been realized that this is not only due to a passive acceptance by organizations of signals from the environment but also that bureaucracies and companies often take in external pressures and mold them in accordance with their history and culture (Thelen and Steinmo, 1992; Yesilkagit and Christensen, 2009) or strategic 
interests (Oliver, 1991; Røvik, 1998).

In our description of the common we will thus focus on answering the following questions:

- What are the characteristics of the ecosystem?

- What are the historical and cultural backgrounds?

- Which technologies affect the way the common is used?

- How is the common seen at different times?

- Which property rights have existed through time and how did they develop?

By answering these questions we will be able to see more clearly how a specific common is being used or overused and changed through time and how the wider society has reacted to this, creating new legal frameworks and new rules for the use of the common. We will make a comparison between two vulnerable ecosystems in China and Denmark. In the beginning, we introduce the ecology of these ecosystems and we sketch some of the developments taking place in these areas related to the use of the common and how they came to a point where measures had to be taken to restore the ecosystems. We then thoroughly describe how rules and regulations have developed in relation to the situation in order to see how new sets of institutional bindings will be created that will hopefully contribute to a more sustainable use of these commons.

\section{The Two Study Areas: Baiyangdian (China) and Mariager Fjord (Denmark)}

\subsection{Baiyangdian Wetland}

Baiyangdian is the last remaining area of numerous wetlands in the Haihe River Basin. Today, Baiyangdian is the largest freshwater body in northern China and is often called 'the Pearl of North China'. Baiyangdian is seen as a representative for wetlands in the semi-arid regions of China.The area of the wetland is $366 \mathrm{~km}^{2}$ (Figure 1) with the area of the wetland changing according to hydrological conditions. The average water depth is $1.5 \sim 2.0 \mathrm{~m}$, and the volume of water is $4 \times 10^{8}$ $\mathrm{m}^{3}$. The optimum water level is $7.74 \sim 8.86 \mathrm{~m}$ above sea level (Zhong et al., 2005). Annual precipitation is $350 \sim 750 \mathrm{~mm}$ and annual evaporation is $1750 \mathrm{~mm}$. As a consequence of global warming, precipitation has gradually decreased while evaporation has increased, resulting in an unbalanced water ecosystem. Human impacts from population growth and industrialization have intensified this trend (Liu et al., 2007).

The catchment of Baiyangdian is mainly low-lying on sandy soil (Wang et al., 1999). The dominant vegetation is reeds (Phragmites australis var. Baiyangdiasis), with a height of roughly $3 \mathrm{~m}$ and covering more than $80 \mathrm{~km}^{2}$, with $\mathrm{Nym}$ phoides peltatum and Lemna minor distributed in the marginal waters around it (Wang et al., 2002).

Baiyangdian differs from other wetlands of southern China as it is divided into 143 lakes and more than 3700 ditches. Around 100,000 people live on small islands in the wetland, so ecological and hydrological processes are affected by severe disturbances from human activities. Contributing to this is the exploitation of water due to population growth and industrial activities in Baoding City, which is located upstream.

Up until the 1950 s, the wetland was in a stable condition. From the 1960s, numerous reservoirs were constructed and water use increased. With decreasing precipitation the wetland shrank significantly. In the 1950 s, the surface area of water was $360 \mathrm{~km}^{2}$, in the $1960 \mathrm{~s}$ it had decreased to $206 \mathrm{~km}^{2}$, reaching an all-time low level in the 1980 s at only $68 \mathrm{~km}^{2}$. After an increase in the $1990 \mathrm{~s}$, it decreased again in 2000 to just 100 $\mathrm{km}^{2}$ (Figure 2) (HRWRC, 2004).

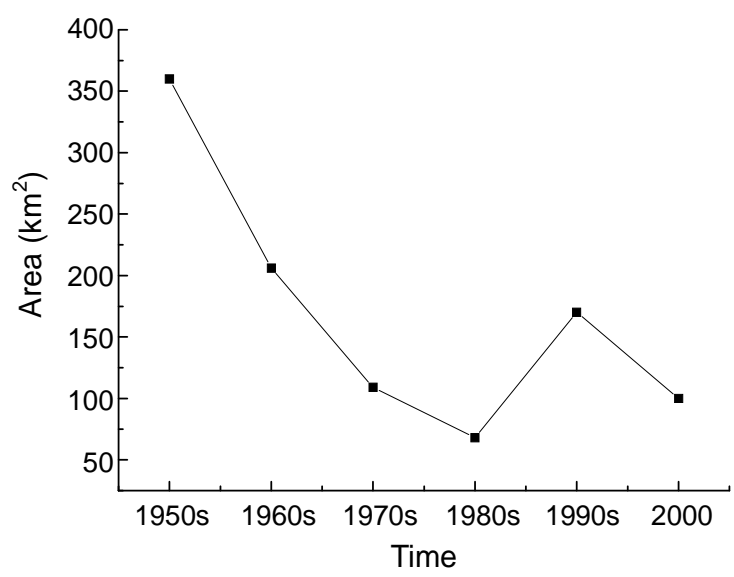

Figure 2. Water surface area change of Baiyangdian since 1950.

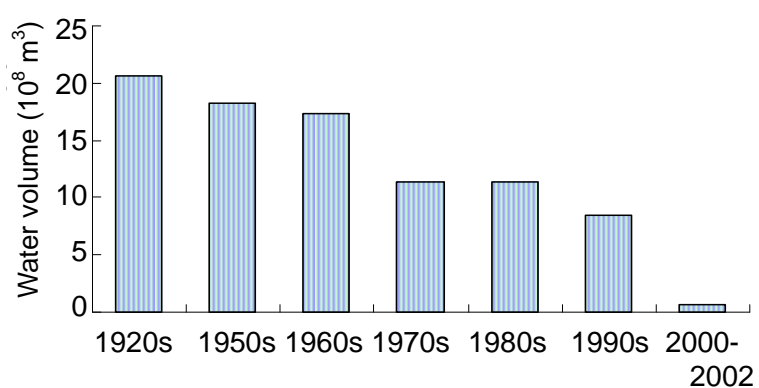

Figure 3. Runoff to Baiyangdian from 1920s to 2002.

In the $1920 \mathrm{~s}$, the annual water flow into Baiyangdian from its tributaries was $20.6 \times 10^{8} \mathrm{~m}^{3}$ but in 1988 it decreased to 12.5 $\times 10^{8} \mathrm{~m}^{3}$. From the $1950 \mathrm{~s}$ to the $1970 \mathrm{~s}$, the amount of water entering the wetland was almost equal to the volume flowing out, so the water level remained stable. From the 1920 s to the present, there have been seven instances of the wetland 'drying up'. From 1984 to 1988, it remained dry throughout all five years (Zhao et al., 2005).

Due to the high volume of water before the 1950s, the water in Baiyangdian was clear and transparent and there were more aquatic species than there are currently. However, since the 1960s runoff has dropped sharply (Figure 3) and the water in Baiyangdian has become almost stagnant and turbid.

Large amounts of untreated sewage and agricultural irrigation water flowing down the $\mathrm{Fu}$ River runs into the wetland bringing with it large amounts of nitrogen $(\mathrm{N})$, phosphorus $(\mathrm{P})$ 
and other nutrients. This has accelerated the deterioration of water quality both in the wetland and the river and has led to events of 'fish killings' appearing at the mouth of the Fu River (Li et al., 2004).

In order to prevent the wetland from drying out again, the State Ministry of Water Resources, together with other authorities, has for ten times since 1992 transferred water from other river systems into Baiyangdian. At present, water is mostly imported to dilute the pollutants in the lake and to ensure the water level remains at the minimum. How much water will be needed in the future and how to allocate it between different users is yet to be determined.

\subsection{Mariager Fjord}

Mariager fjord is the longest of the eight fjords on the east coast of the Jutland peninsula in Denmark (Figure 4). It can be considered a representative for this type of ecosystem in Denmark. The fjord is $42 \mathrm{~km}$ long and it is a 'threshold' fjord situated in a tunnel valley created during the last glacial period. The water in the inner part of the fjord is up to $30 \mathrm{~m}$ deep while the outer part is as shallow as $0 \sim 2 \mathrm{~m}$. The watershed surrounding the fjord is $572 \mathrm{~km}^{2}$, of which $66 \%$ is made up of agriculture, $17 \%$ is forest, $9 \%$ is built-up areas and $8 \%$ is wetlands, lakes and other natural habitats (Århus amt and Nordjyllands amt, 1998b). The soil mainly consists of chalk with a thin layer of sandy soil on top.

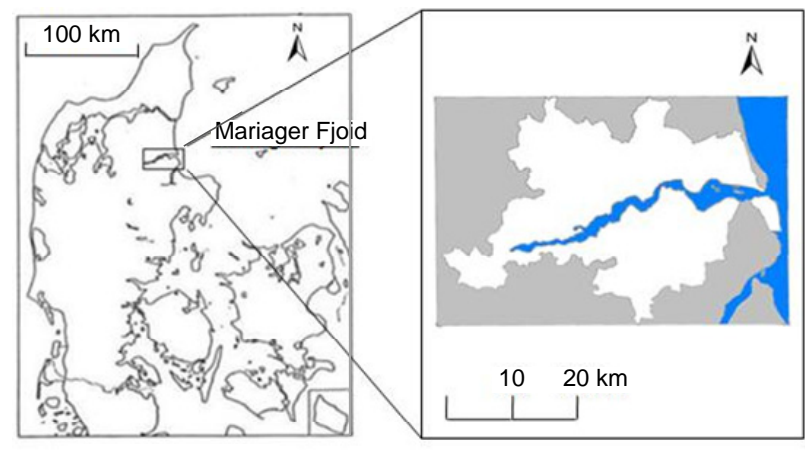

Map of Denmark

Figure 4. Location of Mariager Fjoid.

In the deeper part of the fjord, water circulation is slow, often causing oxygen depletion. The bottom layer of water is also salty $(1.8 \sim 2.4 \%)$, as salt water often intrudes from Kattegat. Approximately two thirds of the water in the fjord comes from Kattegat while one third is fresh water from watercourses and groundwater. The upper layer of water in the fjord is exchanged within a few months, so the resulting salinity is rather brackish $(1.2 \sim 1.7 \%)$. The water in the inner fjord, below $5 \sim 6 \mathrm{~m}$, is found to be depleted of oxygen almost every year.

The levels of nitrogen and phosphorus in the fjord are higher than in any other Danish fjord. In the upper layer of water, the content of tot- $\mathrm{N}$ is above $2000 \mu \mathrm{g} / \mathrm{L}$, while tot-P is above $110 \mu \mathrm{g} / \mathrm{L}$. In the summer, these levels decrease to 1200 and $80 \mu \mathrm{g} / \mathrm{L}$, respectively (Århus amt and Nordjyllands amt, 1998b). The input of nutrients comes from the influx of salt water from Kattegat, from industries and urban waste-water treatment plants, and from aquaculture and agriculture. These human activities have increased throughout the last $100 \sim 200$ years and have contributed to the declining environmental quality.

Table 1. Water Quality Changes of Baiyangdian from 2006 to 2009

\begin{tabular}{llllll}
\hline Time & COD & BOD & Sulphide & Total $\mathrm{Hg}$ & Water quality \\
\hline 2006 & $*$ & & $*$ & $*$ & IV \\
2007 & $*$ & & $*$ & & V \\
2008 & $*$ & & $*$ & & IV \\
2009 & & $*$ & & & IV \\
\hline
\end{tabular}

Note: * means a main contributor of pollution; Levels I-V are the water quality ranking where level I is the best water quality and level $\mathrm{V}$ is the worst. The water quality is based on Environmental Quality Standards for Surface Water in China (MEPC \& SAQSIQ, 2002). (HRWRC, 2006; HRWRC, 2007; HRWRC, 2008; HRWRC, 2009).

Table 2. Examples on Environmental Quality Standards for Surface Water in China (MEPC \& SAQSIQ, 2002) *

\begin{tabular}{|c|c|c|c|c|c|c|}
\hline \multirow[t]{2}{*}{ Items } & & \multicolumn{5}{|c|}{ Classification } \\
\hline & & $\mathrm{I}$ & II & III & IV & V \\
\hline $\mathrm{pH}$ & & $6-9$ & & & & \\
\hline DO & $\geq$ & $\begin{array}{l}\text { Saturation } \\
\text { rate }(90 \%)\end{array}$ & 6 & 5 & 3 & 2 \\
\hline COD & $\leq$ & 15 & 15 & 20 & 30 & 40 \\
\hline $\mathrm{BOD}_{5}$ & $\leq$ & 3 & 3 & 4 & 6 & 10 \\
\hline $\mathrm{NH}_{3}-\mathrm{N}$ & $\leq$ & 0.15 & 0.5 & 1.0 & 1.5 & 2.0 \\
\hline Total N & $\leq$ & 0.2 & 0.5 & 1.0 & 1.5 & 2.0 \\
\hline Total P & $\leq$ & 0.02 & 0.1 & 0.2 & 0.3 & 0.4 \\
\hline $\begin{array}{l}\text { Tot-P for lake } \\
\text { and reservoir }\end{array}$ & $\leq$ & 0.01 & 0.025 & 0.05 & 0.1 & 0.2 \\
\hline
\end{tabular}

* Environmental changes in water temperature $\left({ }^{\circ} \mathrm{C}\right)$ by human beings should be limited to: maximum temperature rise of per week $\leq 1$; maximum temperature drop of per week $\geq 2$.

\section{The History of Increasing Impact}

\subsection{History of Increasing Impact in Baiyangdian}

The Baiyangdian wetland has undergone a complicated historical development since $265 \mathrm{BC}$, when there were far more water resources than at present. After AD 1368, the content of sand in the water increased and some of the rivers silted up. In the 1950s, the Haihe River Basin, where Baiyangdian is located, suffered severely from flooding that washed away houses, damaged farmlands, and killed livestock. In the 1960s, Chairman Mao decided to implement management of the Haihe River Basin and in 1979 the Haihe River Water Conservancy Committee was established in order to draw up water-use plans, to control flood prevention and to monitor water quality. Regular monitoring of Baiyangdian started from this point onwards. The main contributing pollutants to Baiyangdian from 2006 to 2009 and the resulting water quality are shown in Table 1. A definition of the levels of water quality is given in Table 2. 
Since 1980, several hydrological projects have been carried out, mainly to supply drinking water for the cities and to regulate the flow of water into Baiyangdian. This interference with the natural flow minimizes annual fluctuations of the water. The water area is also decreasing as local people have filled the wetlands to create agricultural land. An investigation in 1982 concluded that the area had decreased by $10 \%$ because of this (Zhao et al., 2005). Upstream of Baiyangdian, the annual soil erosion is $1.6 \times 10^{7} \mathrm{~m}^{3}$, so a lot of sand is deposited in the lake. From 1955 to 1979 it was estimated that the deposition of sand caused a decrease in the area of water by $34.8 \%$ (Zhao et al., 2005).

In recent years, studies have taken place in order to improve the water environment and to assess the potential ecological risk of heavy metals in sediments (Yang et al., 2005); protozoan communities were also used to assess water quality (Li et al., 2005). However, only a few studies addressing the whole watershed, as well as water policies, were identified.

Nitrogen and phosphorus influence the growth and reproduction of algae; therefore, they are the main factors controlling eutrophication. In particular, nitrogen $\left(\mathrm{NH}_{4}-\mathrm{N}, \mathrm{NO}_{2}-\mathrm{N}\right.$ and $\left.\mathrm{NO}_{3}-\mathrm{N}\right)$ and soluble phosphorus play crucial roles in eutrophication. The main source of pollution in Baiyangdian is Baoding City and Anxin County, which are both located upstream. The pollution from industry has caused fish and shrimp to die and lead to a decrease in the number of fish species. In addition to the pollution resulting from industry, sewage and garbage from local people pour directly into the lake, and waste from motor vessels and the use of fertilizers and pesticides in agriculture accelarate the deterioration of water quality.

Baoding City's population is now around 600,000. With rising living standards, the use of washing machines and phosphorus-containing detergents has rapidly increased so that urban wastewater emissions of $\mathrm{N}$ and $\mathrm{P}$ have also increased over recent years (Zhang and $\mathrm{Li}, 2007$ ).

\subsection{History of the Increasing Impact in Mariager Fjord}

Even before humans made an impact on the Mariager fjord it probably suffered frequently from oxygen depletion, at least in the inner, deeper part of the fjord. During the last 100 years the fjord has been recorded as being 'dead', i.e. smell of $\mathrm{FeS}_{2}$ and dead fish were found in the years 1933, 1947 and 1970, among others (Århus amt and Nordjyllands amt, 1998b). The latest incidence of 'total death' was recorded in 1997. This event, which is described in more detail below, led to the adoption of the second Danish action plan for the aquatic environment, launched in 1998.

Estimations of the total impacts on the fjord are only available after the 1970 s as the first law on environmental protecttion was passed in 1974, also implying that monitoring more or less started at this point. Prior to 1997 there were some inves tigations into the distribution of eel-grass (Zostéra marina L.). These indicated that the population of eel-grass had decreased due to the increased content of plankton in the water caused by an increase in nutrients. Pollution also led to a decrease in the distribution of the mussel Mytilus edulis, which in the 1930s could be found down to $12 \sim 14 \mathrm{~m}$, whereas in 1997 it only covered the floor of the fjord down to $7 \sim 10 \mathrm{~m}$.

It is no doubt that discharges of polluting substances have increased during the last $100 \sim 200$ years. Back in the late $1800 \mathrm{~s}$ it was recorded that several industries such as dairies, slaughterhouses, and breweries were located in Hobro, the largest city at the end of the fjord. Many of these closed down during the last century, leaving behind just one large dairy today. The population within the watershed has risen slowly to approximately 35,000 inhabitants today, most of them living in Hobro and the towns of Mariager and Hadsund. After the oxygen depletion in 1970, Mariager and Hadsund constructed mechanical/chemical waste-water treatment plants and Hobro and Havndal constructed a mechanical/biological plant. These waste-water treatment plants treated roughly 92,000 PE (person equivalents) of waste water from households and industries.

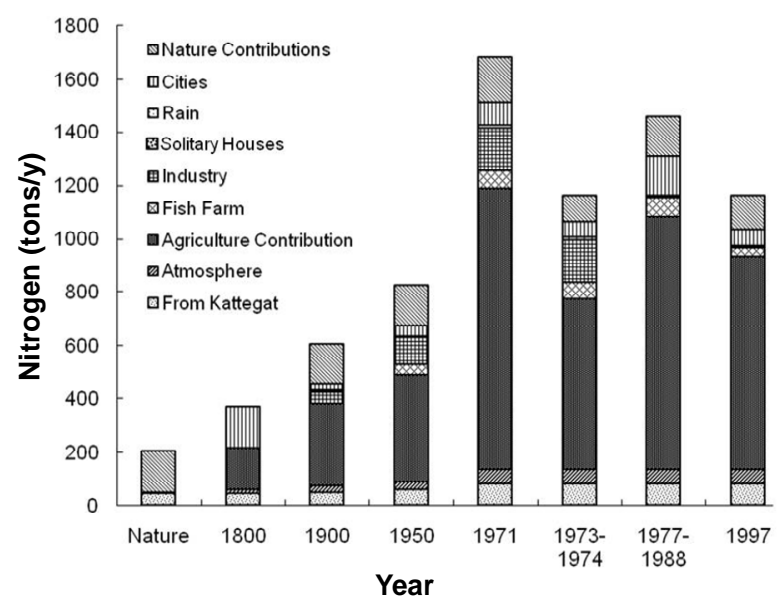

Figure 5. Discharge of nitrogen nutrient to Mariager fjord from 1800 to 1997 (Based on Nordjyllands amt and Århus amt (2004)).

Aquaculture was introduced to the area of Mariager fjord in the 1940s. In 1950 it was recorded that there were six fish farms; this number rose to 17 in 1983 but later declined to 16 in 1996 and by 2002 this number had fallen to 11 (Nordjyllands amt and Århus amt, 2002), and recently it dropped to eight (Nordjyllands amt and Århus amt, 2004). The facilities were small in the beginning, only producing $300 \sim 400$ tons of fish (trout)/year, rising to 815 tons of fish in 1983. All of the facilities were located along the watercourses. From 1960, raw fish was used for feed, but this was banned in 1978. At this point in time, the discharge of nitrogen and phosphorus from aquaculture had reached 68 and 16.8 tons/year respectively (Nordjyllands amt and Århus amt, 2002). In 1983, after the ban on using raw fish, it decreased to 40 tons N/year and 10 tons P/year (Nordjyllands amtskommune, 1986b). Later, aquaculture was regulated by requiring a lower content of phosphorus in the feed. At the time of the 'dead fjord' in 1997, discharge was estimated to be 34 tons of $\mathrm{N}$ and 2.1 tons of $\mathrm{P} /$ year. As part of the action plan to save the fjord, a goal was decided on 22 tons of $\mathrm{N}$ and 1.9 tons of P/year (Nordjyllands 
amt and Århus amt, 2002).

Agriculture has probably covered two thirds of the catchment area over the whole period. Earlier, before the mid-1800s, a large part of this area was uncultivated heath, meadows and commons with very poor soil, thus contributing little to the leaching of nutrients. Most of the marginal land was turned into intensive farming land through the late 1800 s and, as a consequence, the discharge of nutrients rose throughout the twentieth century, especially after the end of World War II when fertilizers became cheaper (see Figure 5). The increased use of nitrogen continued until environmental protection policies started to address this problem in the 1980 s, and since the mid1990s it has been in decline.

In September 1997, Mariager fjord 'died' when an incident of massive oxygen depletion took place. All the fish in the inner fjord died and most of the mussels (Mytilis edulis L.) and eel-grass (Zostéra marina L.) disappeared. This was indeed a national catastrophe. The national politicians reacted by framing a new 'Action plan for the aquatic environment no. II', which increased the demands made on agriculture. The two responsible counties, Århus and Nordjyllands, initiated a process whereby a local action plan for Mariager fjord was to be decided upon.

The total discharge of nitrogen and phosphorus to the fjord in 2000 was 1247 tons and 22.2 tons, respectively (Nordjyllands amt and Århus amt, 2002), with agriculture being the key contributor (see Table 3 ). The goals put forward in the action plan for Mariager fjord (Nordjyllands amt and Århus amt, 2004) stipulated that the discharges of TN and TP should be $550 \sim 620$ tons and $16 \sim 20$ tons, respectively. A working group focusing on the implementation of the Water Framework Directive suggested an even larger reduction to between 200 and 400 tons of $\mathrm{N}$ and between 6 and 8 tons of $\mathrm{P}$ by 2015 (DMU, 2008). If 1247 tons of $\mathrm{N}$ runs off into the fjord each year, as it did in 2000, this would mean that each hectare of the fjord would receive $266 \mathrm{~kg} \mathrm{~N} /$ year, which is more than Danish agriculture uses per hectare of farm land; therefore, eutrophication is indeed a problem.

Table 3. The Nitrogen and Phosphorus Discharges to Mariager Fjord in 2000 (Nordjyllands amt \& Århus amt, 2002)

\begin{tabular}{lll}
\hline & Nitrogen $(\mathrm{N})$ & Phosphorus $(\mathrm{P})$ \\
\hline Aquaculture & 22 & 1.9 \\
Waste-water treatment plants & 49 & 1.9 \\
Urban run-off & 11 & 3.0 \\
Industry & 0.3 & 0.0 \\
Solitary houses & 8 & 1.9 \\
Background contribution & 160 & 7.0 \\
Agriculture & 940 & 6.0 \\
Atmosphere & 57 & 0.5 \\
Total & 1247 & 22.2 \\
\hline
\end{tabular}

The national action plans for the aquatic environment nos. I and II launched in 1987 and 1998, respectively, have reduced the emissions of nitrogen from agriculture by $30 \%$ in the period
$1990 \sim 2002$. This decrease is not visible in Mariager fjord, probably because $75 \%$ of the effluent water goes to groundwater and then slowly finds its way to the fjord (Nordjyllands amt and Århus amt, 2002). This means that it will take 20 30 years before a reduction of $\mathrm{N}$ leaching from the topsoil will appear in the watercourses and the fjord. Therefore, only a slight decline of $\mathrm{N}$ into the fjord has been realized so far, whereas a more substantial reduction in $\mathrm{P}$ has taken place. Presently, the situation of the fjord is not very positive. A report from 2005 stated that the Secchi depth was decreasing and that the goals put forward in the regional plan were far from being met (Nordjyllands amt and Århus amt, 2005), but hopefully the implementation of the Water Plans launched in the spring of 2010 will be able to make substantial progress by 2015, as stipulated in the Water Framework Directive.

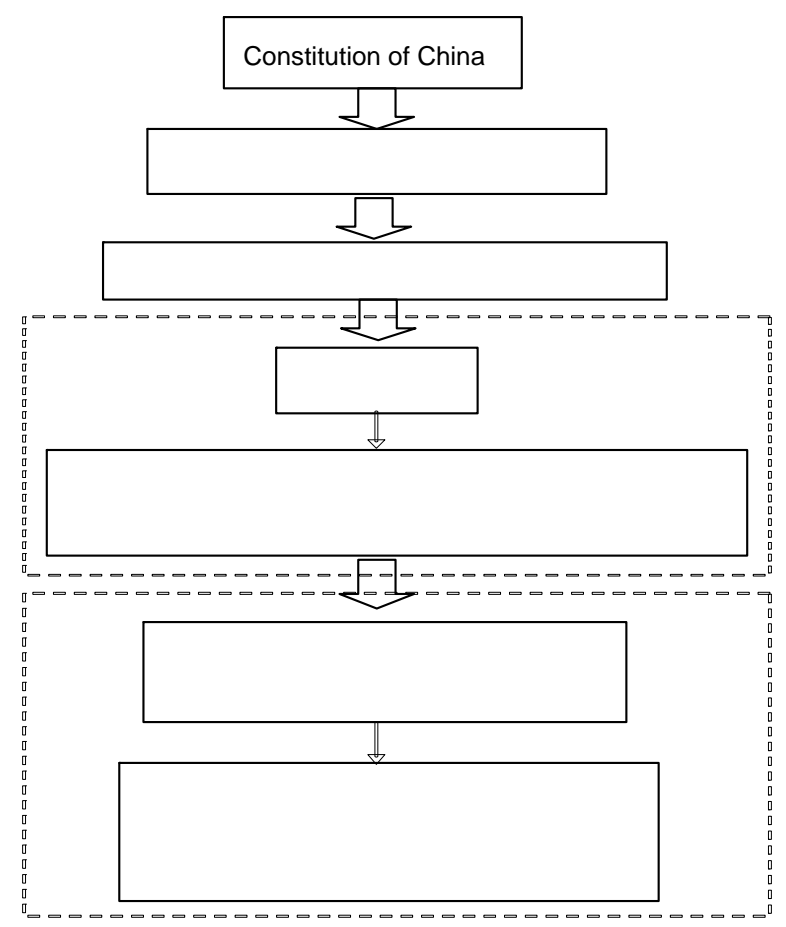

Figure 6. The hierarchy of environmental laws and regulations in China.

\section{The Development of Environmental Regulation and Its Impact on the Two Water Bodies}

\subsection{Environmental Regulation and Its Impact on Baiyang- dian}

In China, the history of protecting the environment started with the Fishery Law in 1929. Today, the Environmental Protection Law first issued in 1979 and amended in1989 is the basis for environmental protection activities.

Before 1949, agriculture played a dominant role and industry was underdeveloped. In the 1950s and 1960s, China went through an economic restructuring, starting with the Great Leap Forward $(1958 \sim 1960)$ and ending with the Cultural Revolution (1966 1976). After a period of recovery, Deng Xiao 
Table 4. Regulations at the Local Level by Hebei Province and Haihe River Water Resources Commission

\begin{tabular}{|c|c|c|}
\hline Regulations & Organization & Effective date \\
\hline Regulations on the management of Baiyangdian water body environmental protection. & $\begin{array}{l}\text { Hebei Province } \\
\text { Government }\end{array}$ & April 22, 1995 \\
\hline Detailed rules for the implementation of a 'Water Permit System' in Haihe River Basin & HRWRC & May 30, 1995 \\
\hline $\begin{array}{l}\text { Examination and monitoring regulation on flood and drought prevention and control in Haihe } \\
\text { River Basin }\end{array}$ & HRWRC & March 23, 2006 \\
\hline
\end{tabular}

Ping started opening up the Chinese economy, which has continued to progress ever since. Pollution from industry was not so heavy earlier on, but during the 1990s it became clear that China was also facing severe problems.

The Environmental Protection Law (1989) is a comprehensive statute which provides the basic principles and systems for environmental protection in China. It requires integration of environmental policy in national economic and social development plans. Focus is on prevention and control as well as the use of Environmental Impact Assessment.

In China, there are four administrative levels in the regulatory system dealing with the environment (Figure 6). The first level is the Constitution, where the goal of sustainable development is formulated.

Below the Constitution are four levels of regulation. The first level is the international environmental treaties, which China has ratified. The second level is the basic laws on the environment, such as the Environmental Protection Law. They formulate the environmental policies, give guidance on environmental protection, and formulate principles and measures. This lays the foundation for the third level containing special laws and regulations, such as those implementing Water Pollution Prevention and Control Law. At this level the regulations are established by the Standing Committee of the National People's Congress. Finally, at the local level, there are environmental regulations established by the provinces or autonomous regions and cities with direct jurisdiction. Furthermore, at the local level, there are administrative bodies defined by their geographical nature, as in the case of Baiyangdian. In Baiyangdian, there are three relevant regulations on protection of the water body, of which two were formulated by the Haihe River Water Resources Commission (HRWRC) and one was formulated by the provincial government (Table 4).

The regulations on environmental protection for Baiyangdian, which were issued by Hebei Province government (see Table 4), are the only regulations focusing solely on Baiyangdian. They define three levels of protection zones. The first protection zone is the area inside the Baiyangdian levee. The second level protection zone starts from the levee and extends 5 miles around it and 10 miles up-river. The third level protection zone includes the rivers flowing into Baiyangdian beyond the first and second protection zones. These form very powerful and clear regulations for the protection of Baiyangdian. In the first and second level it is forbidden to:

- Build any enterprise that could bring pollution to the water body;

- Discharge any poisonous and nocuous fluids, industrial waste or municipal solid waste;
- Clean any vehicles, vessels and containers if petrol, pesticides and other poisonous pollutants are present;

- Use high-risk pesticides;

- Pour surplus oil and waste oil into the water body;

- Discharge solid waste from households and tourist facilities, or manure, into the water body.

For the third level protection zone, it is forbidden to:

- Build or expand heavy pollutant enterprises related to paper pulp production, printing and dyeing, plating and other enterprises that could cause severe environmental pollution;

- Use high-risk pesticides

Today, Baiyangdian is suffering because these regulations are not enforced. When the authors visited the area in April 2009 we saw solid waste piled up on the bank of the islands and several toilets and refuse dumps were also located there. In general, there is no clear definition of what is meant by severe pollution. Furthermore, already existing enterprises that discharge pollutants into Baiyangdian have to pay a sewage charge; therefore, if they can afford to pay, they can pollute at will, without protecting the environment.

Remote sensing maps of Baiyangdian, from 1987, 1999 and 2007 shows that the northwest part of Baiyangdian were being changed from water surface to agriculture land and finally to built up land. While the ecosystem was dramatically being changed, the Regulations on the Management of Baiyangdian Water Body Environmental Protection has not been modified since 1995 when it was issued. The now built up land is within the nature reserve area and thus under the nature reserve areas management regulations.

\subsection{Environmental Regulation and Its Impact on Maria- ger Fjord}

Regulations for environmental protection and nature protection were drawn up 100 years ago (Christensen, 2000). These laws primarily reflected the fact that the impacts from industrialization and urbanization had started to influence the natural environment in Denmark. After World War II, both industry and agriculture began to develop rapidly. Like most other countries, Denmark experienced severe environmental problems in the 1960s leading to the formation of environmental NGOs, an increased focus on ecological sciences and an increased political acceptance of new legislation. This was heralded by the UN Stockholm conference in 1972 (Jamison, 2001), which inspired most countries to adopt environmental legislation. In 1974, a law of environmental protection was 
Table 5. Goals for Mariager Fjord as Stipulated by the First Water Quality Plan form 1986 as well as the Plans for 2001 and 2005 (Nordjyllands amtskommmune, 1986b; Nordjyllands amt, 2001; Nordjyllands amt, 2005)

\begin{tabular}{llll}
\hline & & Inner part of Mariager fjord & Outer part of Mariager fjord \\
\hline \multirow{2}{*}{2986} & Secch depth & $>3 \mathrm{~m}$ & $>3 \mathrm{~m}$ \\
& Tot-N, winter & $<4 \mathrm{mg} / 1$ & $<2.5 \mathrm{mg} / 1$ \\
& Tot-P, winter & $<15 \mu \mathrm{g} / 1$ & $<10 \mu \mathrm{g} / \mathrm{l}$ \\
& Secchi depth & $>4 \mathrm{~m}$ & $>4 \mathrm{~m}$ \\
& Eel-gras (Zostéra sp.) & $>3 \mathrm{~m}$ & $>2 \mathrm{~m}$ \\
\hline
\end{tabular}

launched together with the establishment of a new planning system. The new law included two strong regulatory instruments. First of all, the law included rules for issuing wastewater licenses to industries and waste-water treatment plants. The licenses reflected the goals established in the regional plans as well as in the water quality planning. The other strong instrument was that larger, newly established industries had to obtain an environmental permit before they could start production and existing industries had to obtain one before they could expand. The link between environmental protection and regional planning was strong from the beginning. In the first regional plan in 1981 no goals were formulated for the quality of Mariager fjord but in the regional plan for 1985 a brief goal says that ' $\ldots$ these areas should function as habitats for animal and plant life, and should be able to be used for fishery, bathing and other recreational purposes' (Nordjyllands amtskommune, 1986a). In the first water quality plan for Nordjyllands county in 1986 a goal was set for the Secchi depth and the contents of $\mathrm{N}$ and $\mathrm{P}$ (see Table 5).

At this point it was already clear that the condition of the fjord was not acceptable and as a consequence of the formulated goals the municipalities were obliged to improve their waste-water treatment facilities. The regional plan from 1989 adopted the same measures as presented in Table 5, but it was now underlined that not only should it function as habitats for animal and plant life' but also 'for a versatile animal and plant life' (Nordjyllands amt, 1990). In the regional plan of 1993 the goals were the same but now the conditions had changed. Nitrogen was regulated from 1985 onwards as a result of the action plan for the aquatic environment, so now new demands were mainly made on the discharge of phosphorus (Nordjyllands amt, 1994). While the action plan for the aquatic environment set a general threshold of $1 \mathrm{mg} \mathrm{P} / 1$ of waste water, it was within the discretionary power of the counties to demand lower values. Accordingly, in the regional plan of 1993, the Hobro waste-water treatment plant had a threshold value of $0.4 \mathrm{mg} \mathrm{P} / 1$ while the remaining waste-water treatment plants could continue with $1.0 \mathrm{mg} \mathrm{P} / 1$.

In the regional plan of 1997 major changes occurred as the goals for Mariager fjord were reformulated and strengthened. The general goal was that the fjord '... shall function as habitats for a natural animal and plant life, and therefore have the best possible quality.' (Nordjyllands amt, 1997). It was expected that the inner fjord should live up to this goal whereas the outer fjord should meet more rigorous demands, resulting in a 'condition with a versatile animal and plant life, that only is vaguely impacted by human activities. The composition of animal and plant life is determined by the natural conditions, and the water has a good aesthetic and hygienic quality' (Nordjylland amt, 1997). The reason for the more rigorous demands on the outer fjord is that this area was now designated as a Natura 2000 site. It is only briefly mentioned in the plan that the fjord died in September that same year.

In the regional plan of 2001, the goals were more or less the same as in the previous plan but more quantitative measures were formulated as well (Table 5). There was no authority to regulate agricultural pollution before the first action plan for the aquatic environment was established in 1987. The new instruments established in the action plans were general demands at national level, so the counties could not actually regulate the farms. The achievement of the goals in the regional plans was therefore dependent on other regulatory activities formulated by other governmental bodies.

In the 1970s and 1980s, aquaculture was not required to have an environmental permit as all of the fish farms were established prior to 1974 . Since the late 1980s they have been regulated by general requirements on what kinds of feed can be used, especially regarding the phosphorus content.

Agriculture was not part of the environmental protection law of 1974 either. After severe incidences of oxygen depletion in the 1980s, the first 'Action Plan for the Aquatic Environment' was launched in 1987. This action plan used general rules to reduce the loss of $\mathrm{N}$ from Danish agriculture by $50 \%$. In the mid-1990s, an evaluation estimated that the goals of the action plan had not yet been met and in 1997 the 'death' of Mariager fjord happened. These two events paved the way for the 'Action Plan for the Aquatic Environment II' in 1998. This plan included greater demands on how effectively manure and slurry should be managed, and, furthermore, more emphasis was given to subsidy schemes for nitrate-sensitive areas, afforestation and organic farming.

During 25 years of debate and research, tremendous effortts have been made to reduce the losses of $\mathrm{N}$ and $\mathrm{P}$ from Danish agriculture. Today, the objectives of the first two action plans seem to have been met. This has spurred new discussions on how much further it is necessary to go, as it seems obvious that the first $50 \%$ reduction in the loss of nitrogen has not been enough. The Danish government decided in the 2003 'Action Plan for the Aquatic Environment III' that a further reduction of $13 \%$ was necessary. However, it became clear that this would not be enough if Denmark was to live up to the demands of the EU Water Framework Directive and reach 'good ecological conditions' by 2015. In the drafts for a new action plan launched in 2009 called 'Green Growth' the goals included a further $33 \%$ decrease of $\mathrm{N}$ discharged to the ma- 
rine environment. This means that after the first $50 \%$ reduction that was decided on in 1987 , it was then decided that a further halving of the remaining $\mathrm{N}$ loss to the coastal waters was necessary.

After the death of Mariager fjord in 1997, the local politicians in Århus and Nordjyllands counties decided to draw up a local action plan for the fjord. In February 1998, an 'idea catalogue' was formulated that discussed many of the technological and regulatory possibilities for 'saving the fjord' (Århus amt and Nordjyllands amt, 1998a). Many of these ideas were rather unrealistic, such as oxygenation of the fjord or removal of sludge from the bottom of the fjord. After these initial discussions, the next four years were more or less spent documenting the status of the fjord in a long series of reports covering different aspects of the fjord's ecosystem (Trelle Christensen, 2007). Finally, in 2002, the counties invited the public to take part in a discussion on the future of the fjord (Nordjyllands amt and Århus amt, 2002). In a leaflet, the counties underlined the fact that the national policy in the previously formulated 'Action plans' was not sufficient to safeguard the fjord. Goals have now been set by the EU Water Framework Directive, whereby conditions will hopefully improve so that a 'good ecological condition' can be attained. The local action plan was never established but the idea behind it was very much the same as the Water Plans outlined in the Water Framework Directive. The first generation of Water Plans was launched in January 2010 and they will work towards attaining 'good ecological conditions'.

\section{Comparison of the Environmental Capacity in China and Denmark}

When comparing the two case studies, we concentrated on the five questions previously mentioned:

- What are the characteristics of the ecosystem?

- What are the historical and cultural backgrounds of the society?

- Which technologies affect the way the common is used?

- How is the common seen at different times?

- Which property rights have existed through time and how did they develop?

\subsection{What are the Characteristics of the Ecosystem?}

The two cases share some common features but there are also wide differences between them. Denmark is a small country with little ecological variation. The temperate Atlantic climate and its position at the northern part of continental Europe bring Denmark a beautiful and mild environment and the country is lush and green. China's land area is almost 240 times greater than that of Denmark, so naturally it is richer in different climates and has a broader variety of natural habitats, ranging from temperate climates such as the one in Denmark to tropical regions in the southernmost part to arid and desert areas in the northern part of the country. The case study areas are alike in many respects, both having a temperate climate and lakes/fjords that face problems with eutrophication. There are human settlements, industries and farmland in both areas that impact on the ecological balance. In Baiyangdian, the hydrological balance is also disturbed due to excessive use of water in this basically semi-arid region.

\subsection{What are the Historical and Cultural Backgrounds of the Society?}

Looking at the two countries with a broader historical and cultural perspective unveils some dramatic differences but also some striking similarities. Denmark, as a member of the $\mathrm{EU}$, is among the richest countries in the world (GDP US \$ 37,400 ). China is still a developing country and although it has had fabulous growth rates for many years it has not yet caught up in GDP, which is now US\$ 6000 per capita.

As a small country Denmark has few administrative le-vels and thus it is simpler to implement legislation and policies, whereas China has more levels of bureaucracy. Furthermore, China has always been more bureaucratic due to its cultural background as well as its recent history. While Danish society is based on market economy and democracy, China is a socialist country based on a one-party system. In a certain sense, however, Denmark and China have common features when it comes to collectivist behavior; working and acting as a group or in co-operation with others. Even today, this is the backbone of the two societies; in China this entails collectivist behavior and loyalty (Bell, 2008) and in Denmark a certain degree of collectivism is paired with individualism (Bjørn, 1998). There is a high degree of trust in and loyalty to the government and legislation in both countries. For the Danes, the reason for this trust is the participative democracy that evolved from the folk high school movement and the cooperative movement (Bjørn, 1998), whereas for the Chinese, this trust stems from the notion of loyalty to those in leadership, and it dates back to the days of Confucius and Imperial China (Bell, 2008).

Denmark has experienced a modernization period while China has been hindered by its troubled socio-political situation. This has resulted in the Danish society taking up capitalism much earlier (1848) than China (1980), and thus transforming itself into more of an individualistic nation when it comes to the economy, although still retaining much of its collectivist attitude, as can still be seen in the Danish welfare system today.

\subsection{Which Technologies Affect the Way the Common is Used?}

The area around Mariager was industrialized at an early date, with several industries in Hobro and the other cities along the fjord. For agriculture, a wave of land reclamation was initiated after the defeat to Germany in the war of 1864, when Denmark lost the southern part of Jutland. Under the motto 'What is lost outside must be regained internally', heath land was turned into farmland and marginal soils were afforested. Later on, the industrialization of farming took place, especially after World War II when tractors, artificial fertilizers and, later, pesticides were introduced. 
Since 1970 a range of new technologies has been introduced to combat pollution. First, these dealt with waste-water treatments for cities and polluting industries, together with landfill. Later on in the 1980s and 1990s, cleaner technologies were introduced, especially for industries, but at that time many companies closed or moved to other places with less strict environmental regulations. Many companies also became conected to municipal waste-water treatment plants which from 1990 onwards were required to be modern, highly advanced treatment facilities. Agriculture faced environmental regulations from 1987, and a lot of new technologies have been introduced to minimize pollution. Aquaculture grew from the 1920 s to 1990 . Since then, this industry has been regulated by requirements put on the feed. Many aquaculture farms have been closed in order to protect the flow of water in the watercourses, and new 'full recirculation' aquaculture farms have been developed.

Our knowledge of how technology plays a role in Baiyangdian is scarcer. We know for sure that the population and affluence has increased and that new household appliances have been introduced. We also know that several companies have established themselves in Baoding and continue to cause problems as the environmental regulations are still insufficient and the technologies used are probably somewhat old fashioned and not aimed at pollution prevention. In terms of agriculture, the technologies are also fairly old-fashioned; some are even so old that they do not cause much pollution. However, this fact also demands caution as an increase in agricultural production will pay a price in that losses of $\mathrm{N}$ and $\mathrm{P}$ will increase. Finally, Baiyangdian is also affected by hydrological projects that store water for supplying to the local residents and for regulating the flow of water in Baiyangdian.

Measures of pollution abatement and prevention are not as prevalent in the Baiyangdian area as around Mariager fjord. On our visits to the two places we noticed a marked difference, for example, piles of waste along parts of Baiyangdian shores, which indicates that many places around Baiyangdian lack the technological means to prevent pollution.

\subsection{How is the Common Seen at Different Times?}

Both water bodies have a special place in the hearts of people living alongside them and visitors alike. Baiyangdian is called 'the pearl of Northern China' owing to its rich resources of lakes and lotus flowers. Likewise, Mariager fjord is well known for its beauty and many people have sailing boats in one of the many local harbors. Also, during the incident known as the 'death of the fjord', it became clear that a lot of feelings were attached to the place and what happened was genuinely seen as a catastrophe. Besides this, the two areas have been regarded as places to make a living, and, more specifically, as places that could digest and transform sewage and run-off from the farmland. They have been seen as robust recipients for many years - and maybe they were. But now, as a result of increasing pollution, this notion of a self-cleaning capacity is on its way out. Now the two areas are seen as fragile environments that should be protected and even 'res- tored' back to a condition where the balance between human use of the environment and its protection for non-production purposes has struck a new balance. This has happened at different times for different categories of people and this process has definitely come further along in Denmark than in China. This balance between production and protection is, of course, not formulated in the same way in the two countries as this process has moved faster and wider in Mariager fjord than Baiyangdian. Denmark has also accomplished a large degree of environmental policy integration (EPI), which is not the case in China (Bina, 2008; Zhang and Wen, 2008). In this respect China, as with technology, is 'lagging behind' the situation in Denmark and its way forward will be more bumpy and will meet more resistance than was the case for Denmark.

\subsection{Which Property Rights have Existed through Time and How did They Develop?}

A comparison of the laws and regulations in China and Denmark definitely shows some marked differences. Both countries began to introduce some 'environmental laws' many years ago but it was only after the UN conference in Stockholm that industrial pollution was targeted. Both countries have since formulated new laws and regulations that look fine on paper, but in reality the legislation in China has not been fully implemented, for which there might be several reasons. One could be the weak level of enforcement and another could be the rather complicated administrative structure, where several levels of jurisdiction are responsible for the management of the wetland, a situation that causes many conflicts. For example, Baiyangdian is the responsibility of the Haihe River Water Resources Commission, which is an affiliate of the Ministry of Water Resources. It is also regulated by the local government of Hebei province. The areas of authority of these two management departments overlap and are also possibly in conflict. In some cases, people living beside the wetland are still filling the lake with soil to reclaim it for farmland. This is supported by the Land Department but is opposed by the environmental protection departments because it threatens the wetland ecosystem. Aquaculture is supported by the Fishery Department, but it is of concern to the environmental protecttion departments (Sang, 2006).

Xiao and colleagues $(2006 \mathrm{a}, 2006 \mathrm{~b})$ claimed that there is already a very complete set of legislations that could be used for protecting the Baiyangdian wetland. But in our view, the coordination between national and local regulations, as well as the lack of proper enforcement, definitely constitutes a barrier against success.

There is also a complicated legislative structure around the Mariager fjord in Denmark. Prior to 2007, it was the counties that were the main authorities responsible for the planning related to nature and the environment. The two counties of Nordjylland and Århus succeeded in working together to create a joint vision and a common action plan. After 2007, a new and slightly more complicated structure was established which consisted of the municipalities as well as seven new State Environmental Centres. The Water Plans demanded by the EU 
Water Framework Directive shall now be formulated by these national centers, and then the municipalities in the watershed of the fjord will be obliged to implement these visions. The first generation of Water Plans has been drafted and it seems reasonable to assume that it will be implemented by 2015 or 2021 and that Mariager fjord should then be close to the natural conditions which prevailed before industrialization.

New laws have been and are being formulated in both countries. In China, the environmental legislation appears to be unable to stop environmental degradation. Contrary to this, the situation in Denmark is constantly improving, but this has demanded clear goals that have been pursued for many years as well as strict limits being placed on polluting activities. This has been done through several consecutive 'Action Plans' issued over 25 years, which demonstrates the clear visions of the politicians and a continuous will to implement the necessary rules and regulations.

Pollution in Denmark was very severe in the 1970s but the government has succeeded in establishing a meticulous net of regulations that are implemented well and that can be used to reduce pollution step by step. The visionary goals of creating freshwater and marine habitats that live up to the ideal of achieving a 'good ecological condition', as stipulated by the EU, seem to be realistic targets for the coming decade.

In China, visions have now been formulated that could be helpful in restoring Baiyangdian. Presently, Baiyangdian has been divided into three zones in accordance with 'The Nature Reserve Ordinance' from 1994 which clearly stipulates that access is forbidden to the core zone, only scientific research and observations are allowed in the buffer zone, and both scientific research and exploitation are allowed in the experimental zone. This will hopefully provide a platform for handling the problems at Baiyangdian.

\section{Conclusions}

Comparing the two wetlands - Baiyangdian in China and Mariager fjord in Denmark - paints a picture of the differences between the two countries. In many ways a culturalcognitive comparison clearly shows that in both Denmark and China it can be expected that goals, once they are decided upon, will be implemented. But, in reality, it seems that this will be easier to accomplish in Denmark than in China, probably due to the complicated administrative structure in China and the clearer goals and better resources in Denmark. Due to its level of economic development, Denmark started out earlier, building up an effective environmental administration. Likewise, China started after the Stockholm conference in 1972, but it did not succeed in formulating effective legislation, as happened in Denmark during the 1980s. During this period, Denmark strengthened its environmental regulation by demanding more efficient waste-water treatment plants and that companies improve their environmental performances through the use of cleaner technologies. These kinds of visions first found their way into Chinese regulations in the mid1990s and for the Baiyangdian area they presumably have not had much impact yet. Furthermore, Denmark started regula- ting agriculture much earlier,whereas it is debatable how far China has come down that road.

The complicated administrative structure and China's continuous focus on growth makes improvement difficult but things are changing and we have seen that China has started to count the environment among its top priorities, realizing that the balance between economic growth and environmental protection should be reconsidered, which is definitely a good starting point for catching up.

Acknowledgments. The present research was supported by the National Basic Research Program of China (973) (No.2006CB403 403), the National Water Pollution Control Major Project of China (2008ZX07209-009) and the Innovation Method Fund of China (2008IM020700). We wish to thank two anonymous reviewers for useful comments which helped improve this paper.

\section{References}

Århus amt, and Nordjyllands amt (1998a). Idekatalog - en ren Mariager Fjord (Idea cataloque - A clean Mariager Fjord). February 1998. (in Danish)

Århus amt, and Nordjyllands amt (1998b). Mariager Fjord. Udvikling og status 1997 (Mariager Fjord. Development and status). Århus amts trykkeri, August 1998. (in Danish)

Bell, A.D. (2008). China's New Confucianism. Politics and Eveyday Life in a Changing Society. Princeton University Press, Princeton, USA.

Bina, O. (2008). Relevance of Europe's Environmental Policy Integration Concept for China: Evidence of de facto EPI and questions about effectiveness. Ecologic - Institute for International and European Environmental Policy, Berlin. August 2008.

Bjørn, C. (1998). Dengang Danmark blev moderne (When Denmark became modern). Forlaget Fremad A/S, Copenhagen. (In Danish).

Christensen, P. (2000). Kampen om vandet (The struggle over water). Aalborg Universitetsforlag. (In Danish)

Commoner, B. (1971). The Closing Circle. Bantam Books, New York.

Costanza, R., and Folke, C. (1996). The Structure and Function of Ecological Systems in Relation to Property-Rights Regimes. In S. Hanna, C. Folke Mäler C.F. (eds.): Rights to Nature. Ecological, Economic, Cultural, and Political Principles of Institutions for the Environment. pp. 13-34. Beijer International Institute of Ecological Economics, The Royal Swedish Academy of Sciences, Stockholm; Island Press, Washington DC.

DiMaggio, P.J., and Powell, W.W. (1983). The Iron Cage Revisited: Institutional Isomorphism and Collective Rationality in Organizational Fields, Am. Socio. Rev., 48, 147-160. http://dx.doi.org/ $10.2307 / 2095101$

DMU. (2008). Analyse af miljøtilstanden i Mariager Fjord fra 1986 til 2006 (Analysis of state of the environment in Mariager fjord from 1986 to 2006). Faglig rapport fra DMU, nr. 685, National Environmental Research Institute, Copenhagen. (In Danish).

HRWRC (Haihe River Water Resources Commission). (2004). Investigation and Assessment on Water Resources Development and Utilization of Haihe River Basin (revised) 6, 92. (in Chinese).

HRWRC (Haihe River Water Resources Commission). (2006). Haihe River Basin Water Quality Bulletin (2006 annual summary). (in Chinese).

HRWRC (Haihe River Water Resources Commission) (2007). Haihe River Basin Water Quality Bulletin (2007 annual summary). (in Chinese).

HRWRC (Haihe River Water Resources Commission). (2008). Haihe 
River Basin Water Quality Bulletin (2008 annual summary). (in Chinese).

HRWRC (Haihe River Water Resources Commission). (2009). Haihe River Basin Water Quality Bulletin (2009 annual summary). (in Chinese).

Hanna, S., and Munasinghe, M. (1995). An Introduction to Property Rights in a Social and Ecological Context. In S. Hanna and M. Munasinghe (eds.) Property Right in a Social and Ecological Context. Case Studies and Design Applications. Beijer International Institute of Ecological Economics and the World Bank, Washington, USA. 3-11.

Hardin, G. (1968). The Tragedy of the Commons, Science, 162, $1243-$ 1248. http://dx.doi.org/10.1126/science.162.3859.1243

Jamison, A. (2001). The Making of Green Knowledge: Environmental Politics and Cultural Transformation, Cambridge University Press, Cambridge. http://dx.doi.org/10.1017/CBO9780511489 143

Kuhn, T. (1962). Videnskabens revolutioner. Fremad, Copenhagen 1973. (in Danish).

Li, F.C., Shen, Y.F., and Liu, C.Q. (2005). Assessment of the Water Quality Using Protozoan Communities during Low Water Period in Baiyangdian lake, Chin. J. Ecol., 24(7), 785-789. (in Chinese).

Li, J.G., Li, G.B., and Cui, H.M. (2004). Degradation of Reed Wetland and Protection in Baiyangdian, South-to-North Water Transfers Water Sci. Technol., 2(3), 35-38. (in Chinese). http://dx. doi.org/10.3969/j.issn.1672-1683.2004.03.012

Liu, C.L., Xie, G.D., and Xiao, Y. (2007). Impact of Climatic Change on Baiyangdian Wetland, Res. Environ. Yangtze Basin, 16(2), 245-250. (in Chinese). http://dx.doi.org/10.3969/j.issn.1004-8227. 2007.02.023

March, J., and Olsen, J.P. (1989). Rediscovering Institutions. The Organizational Basis of Politics. The Free Press. New York.

Meyer, J.W. (1994). Rationalized Environments. In W. Richard Scott and John W. Meyer, (eds.) Institutional Environments and Organizations: Structural Complexity and Individualism, pp. 28-54 Sage.

MEPC (Ministry of Environmental Protection of China), and SAQSIQ (State Administration of Quality Supervision, Inspection and Quarantine). (2002). Environmental quality standards for surface water (GB3838-2002). (in Chinese).

Nordjyllands amt (1990). Regionplan Nordjylland 1989-2001. Bind 1. Retningslinier og redegørelse. (Regional plan Northern Jutland County). (In Danish).

Nordjyllands amt (1994). Regionplan '93. Retningslinier og redegørelse. (Regional plan Northern Jutland County) (In Danish).

Nordjyllands amt (1997). Regionplan '97. Retningslinier og redegørelse. (Regional plan Northern Jutland County) (In Danish).

Nordjyllands amt (2001). Regionplan 2001. Retningslinier og redegørelse. (Regional plan Northern Jutland County) (In Danish).

Nordjyllands amt (2005). Regionplan 2005. Retningslinier og redegørelse. (Regional plan Northern Jutland County) (In Danish).

Nordjyllands amt, and Århus amt (2002). Debatoplæg om Mariager Fjord. (Debate on Mariager fjord) February 2002. (In Danish).

Nordjyllands amt, and Århus amt (2004). Mariager Fjord. Indsatskatalog for nedbringelse af tilførelsen af fosfor og kvælstof Mariager Fjord. Action Plan for reduction of Phosphorus and Nitrogen). April 2004. (In Danish).

Nordjyllands amt, and Århus amt (2005). Vestlige Kattegat og tilstødende fjorde 2004. Tilstand og udvikling. (Western Kattegat and Adjacent Fjords 2004. Condition and Development). May 2005. (In Danish).

Nordjyllands amtskommune (1986a). Regionplan 1985-97. (Regional plan Northern Jutland County) (In Danish).

Nordjyllands amtskommune (1986b). Recipientkvalitetsplan. (Water Quality Planning). Bind 2. Kystvandene - Mariager Fjord, Katte- gat, Skagerak. June 1986. (In Danish).

Oliver, C. (1991). Strategic responses to institutional processes, Acad. Manage. Rev., 18(1), 145-179.

Ostrom, E. (1999). Coping with Tragedies of the Commons. Annu. Rev. Polit. Sci., 2, 493-535. http://dx.doi.org/10.1146/annurev.poli sci.2.1.493

Ostrom, E., Burger, J., Field, C.B., Norgaard, R.B., and Policansky, D. (1999). Revisiting the Commons: Local Lessons, Global Challenges, Science, 284 (5412), 278-282. http://dx.doi.org/10.1126/sci ence. 284.5412.278

Røvik, K.A. (1998) Moderne organisasjoner: Trender i organisasjonstekningen ved tusenårsskiftet. (Modern organisations: Trends in organizational thinking at the millenium. Bergen-Sandviken: Fagbokforlaget. (In Norwegian).

Sang, J.S. (2006). Lawmaking for Management and Protection of Wetlands in China, Wetland Sci. Manage., 2(3), 50-53. (in Chinese). http://dx.doi.org/10.3969/j.issn.1673-3290.2006.03.009

Scott, W.R. (2001). Institutions and Organizations. Sage.

Thelen, K., and Steinmo, S. (1992). Historical Institutionalism in Comparative Politics. Pp 1-32 in S. Steinmo, K. Theleen and F. Longstreth (eds.) Structuring Politics. Historical Institutionalism in Comparative Analysis. Cambridge University Press. http://dx.doi. org/10.1017/CBO9780511528125.002

Trelle Christensen, L. (2007). Natura 2000 \& Vandrammedirektivet. Fremtidig betydning for indsatsplanlægningen for Mariager Fjord. Studenterprojekt. Environmental Management. 9. semester 2007. Aalborg Universitet. (in Danish).

Wang, W.D., Wang, D.L., and Yin, C.Q. (2002). A Field Study on the Hydrochemistry Of Land/Inland Water Ecotones with Reed Domination, Acta hydrochim. hydrobiol., 30(2-3), 117-127. http://dx. doi.org/10.1002/1521-401X(200211)30:2/3<117::AID-AHEH117> 3.0.CO;2-3.

Wang, X.J., Ye, C.M., Lei, Z.F., and Gong, A.J. (1999). Characterization of the Agricultural Soil of the North Bank of Baiyangdian Lake, Adv. Environ. Sci., 7(2), 110-115. (in Chinese).

Xiao, H., Chen, C.Y., Wei, Q., and Liu, Z.D. (2006a). The status quo, Problems and the Function of Legislation on Wetlands in Hebei Province, Hebei For. Sci. Technol., 1, 33-34 (in Chinese).

Xiao, H., Liu, Z.D., Chen, C.Y., and Wei, Q. (2006b). The Legislative status quo of Wetlands around the World and the Enlightenment for the Wetlands Legislation of Hebei Province in China, Hebei For. Sci. Technol., 2, 40-41 (in Chinese).

Yang, Z., Li, G.B., Wang, D.W., and Cui, H.M. (2005). Pollution and the Potential Ecological Risk Assessment of Heavy Metals in Sediment of Baiyangdian Lake, J. Agro-Environ. Sci., 24(5), 945951. (in Chinese).

Yesilkagit, K., and Christensen, J.G. (2009). Institutional Design and Formal Autonomy: Political versus Historical and Cultural Explanations, J. Public Admin. Res. Theory., 20, 53-74. http://dx.doi. org/10.1093/jopart/mup002

Zhang, Y., and Li, W.T. (2007). Water Environment Status and Suggestions for Protection of Lake-type Wetland in Hebei Province, South-to-North Water Transfers Water Sci. Technol., 5(1), 78-81. (in Chinese). http://dx.doi.org/10.3969/j.issn.1672-1683.2007.01.026

Zhao, X., Cui, B.S. and Yang, Z.F. (2005). A study of the Lowest Ecological Water Level of Baiyangdian Lake, Acta Ecol. Sin., 25(5), 1033-1040. (in Chinese).

Zhang, K.M., and Wen, Z.G. (2008). Review and challenges of policies of environmental protection and sustainable development in China, J. Environ. Manage., 88, 1249-1261. http://dx.doi.org/ 10.1016/j.jenvman.2007.06.019

Zhong, P., Yang, Z.F., and Cui, B.S. (2005). Studies on Water Resource Requirement for Eco-Environmental Use of the Baiyangdian Wetland, Acta Sci. Circumst., 25(8), 1119-1126. (in Chinese) 